\title{
A Biosensor based on Immobilization of Lactate Oxidase in a PB-CTAB Film for FIA Determination of Lactate in Beer Samples
}

\author{
Denise Lowinsohn and Mauro Bertotti* \\ Instituto de Química, Universidade de São Paulo, 05508-900 São Paulo-SP, Brazil
}

\begin{abstract}
No presente trabalho são apresentados resultados referentes à fabricação de um biossensor para análise de lactato. O dispositivo foi preparado imobilizando-se a enzima lactato oxidase em filme de Azul da Prússia (PB, sigla em inglês) depositado na superfície de eletrodo de carbono vítreo em soluções de CTAB. Nestas condições experimentais observou-se melhoria na sensibilidade e seletividade das determinações de lactato, as quais foram conduzidas em sistema FIA com detecção amperométrica. Nas condições otimizadas $(\mathrm{pH}=6,9$ e $\mathrm{E}=-0,1 \mathrm{~V})$, obteve-se curva analítica com limite superior igual a $0,28 \mathrm{mmol} \mathrm{L}^{-1}$ e um limite de detecção de $0,84 \mu \mathrm{mol} \mathrm{L} \mathrm{L}^{-1}$. A repetibilidade do método foi avaliada por meio de injeções consecutivas de amostras de lactato $0,28 \mathrm{mmol} \mathrm{L}^{-1}$, obtendo-se desvio padrão de $2,2 \%(\mathrm{n}=18)$. O método foi aplicado em amostras de cerveja e houve boa concordância entre os resultados obtidos e aqueles oriundos do uso de procedimento espectrofotométrico de referência.
\end{abstract}

An amperometric lactate biosensor with lactate oxidase immobilized into a Prussian Blue (PB) modified electrode was fabricated. The advantage of using cetyltrimethylammonium bromide $(\mathrm{CTAB})$ in the electrodeposition step of PB films onto glassy carbon surfaces was confirmed taking into account both the stability and sensitivity of the measurements. The biosensor was used in the development of a FIA amperometric method for the determination of lactate. Under optimal operating conditions $(\mathrm{pH}=6.9, \mathrm{E}=-0.1 \mathrm{~V})$, the linear response of the method was extended up to $0.28 \mathrm{mmol} \mathrm{L}^{-1}$ lactate with a limit of detection of $0.84 \mu \mathrm{mol} \mathrm{L}^{-1}$. The repeatability of the method for injections of a $0.28 \mathrm{mmol} \mathrm{L}^{-1}$ lactate solution was $2.2 \%(\mathrm{n}=18)$. The usefulness of the method was demonstrated by determining lactate in beer samples and the results were in good agreement with those obtained by using a reference spectrophotometric enzyme method.

Keywords: lactate, biosensor, prussian blue modified electrodes, CTAB, FIA amperometric detection, beer

\section{Introduction}

The relevance of metal hexacyanoferrates for electroanalytical chemistry was firstly demonstrated in the pioneering studies of Itaya et al. ${ }^{1,2}$ involving the electrocatalysis of oxygen and hydrogen peroxide reduction at surfaces covered by Prussian Blue (PB, iron(III) hexacyanoferrate(II)) films. The transfer of electrons and the movement of small hydrated counter-cations through the channels and holes of the solid for charge compensation is a typical feature of this kind of compound. Owing to the zeolite nature of metal hexacyanoferrates, their ability as effective three-dimensional electrocatalysts has been extensively recognized.

\footnotetext{
*e-mail: mbertott@iq.usp.br
}

Once sufficient negative potentials are applied to PB modified electrodes, electrons are injected into the film and the so-called Prussian-White film is generated which arises from the reduction of a high-spin $\mathrm{Fe}^{3+}$. The reduced form $\left(\mathrm{Fe}^{2+}\right)$ is catalytically active towards the electron-transfer step involving hydrogen peroxide, water being formed as a final product. At positive potentials, PB films are also able to mediate the oxidation of hydrogen peroxide to oxygen in a process that takes place with the participation of the low-spin $\mathrm{Fe}(\mathrm{CN})_{6}^{3-}$ species.

The high catalytically activity and selectivity of $\mathrm{PB}$ films and analogues regarding the cathodic reduction of hydrogen peroxide has been previously reported. ${ }^{3-6}$ The use of hexacyanometallates containing transition metals has also been investigated to modify electrode surfaces and the electrocatalytic properties of these interfaces have also 
been demonstrated regarding oxidative processes..$^{7-12}$

A main drawback found when PB modified electrodes are applied for electroanalytical purposes is the poor stability of the film at potentials where Prussian White is cathodically generated..$^{13}$ Such negative potentials are required for selective monitoring of hydrogen peroxide in samples containing reducing species. An aspect to be taken into account regarding the response in long-term monitoring is the influence of the $\mathrm{pH}$ increase in the vicinity of the film as hydrogen peroxide is reduced. ${ }^{4}$ Accordingly, the stability of PB modified electrodes during hydrogen peroxide monitoring is strongly increased if measurements are performed in buffer solutions. The incorporation of $\mathrm{Ru}(\mathrm{III})$ ions into the PB film has also been suggested for minimizing the solubilisation process..$^{14,15}$ The formation of mixed-valent dinuclear $\mathrm{Ru}-\mathrm{Fe}$ oxo-bridges contributes to the immobilization of a more insoluble material onto the electrode surface with a consequent increased chemical and electrochemical stability. Another procedure has been reported recently and it is based on the electrodeposition of PB films in solutions containing cetyltrimethylammonium bromide, CTAB..$^{16-18}$ Besides the film stability, the sensitivity of hydrogen peroxide determinations is enhanced because of the incorporation of high-spin $\mathrm{Fe}^{3+}$ ions into the $\mathrm{PB}$ lattice interstitial channels when the film is prepared in surfactant medium.

Amperometric biosensors are the most commercially successful devices to monitor the concentration of analytes in a simple, friendly and non-expensive way. In the majority of the biosensors the recognition element is a biological material such as an enzyme and its incorporation into the electrode surface offers the required selectivity because of current arises from analyte-specific reactions at the working electrode. Accordingly, the use of PB and analogues modified electrodes to fabricate biosensors has been extensively described in literature, the enzymes being immobilized onto the surface of the film by different techniques. ${ }^{19-22}$

Lactate is the key metabolite of anaerobic glycolytic pathway and its accurate determination is in growing demand in many fields such as clinical and sport medicine and the fermentation industry. Accordingly, we have already proposed the fabrication of a blood lactate biosensor and the influence of physical exercise on the lactate levels was clearly evidenced. ${ }^{23}$ In this work we have evaluated the possibility of using such a device for the determination of lactate in beer samples by using a flow injection analysis method. The detection is based on the principle that lactate is converted to pyruvate and hydrogen peroxide by lactate oxidase. The enzyme was immobilized onto a PB modified film polarized at adequate potentials for measuring the generated hydrogen peroxide (Scheme 1). Investigations on the use of CTAB in the film preparation step were carried out as an attempt to improve the stability and sensitivity of the amperometric detector.

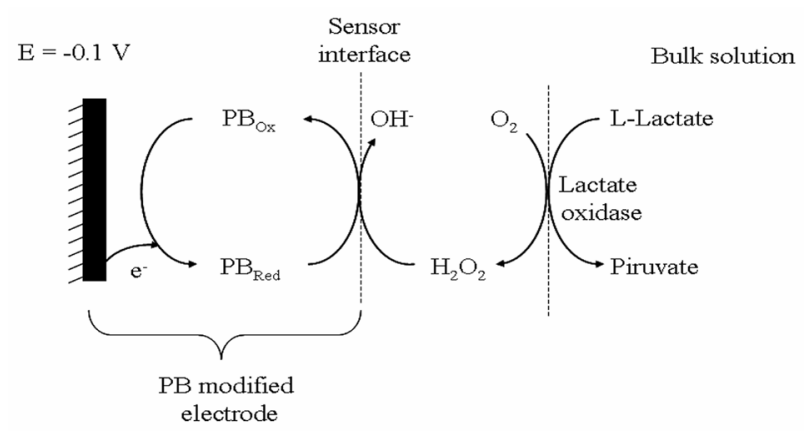

Scheme 1.

\section{Experimental}

\section{Chemicals}

Lactate oxidase (LOX, E.C. 232-841-6) from Pediococcus species containing 47 units $\mathrm{mg}^{-1}$ solid was obtained from Sigma Aldrich Co. (St. Louis, MO). The stock solution was prepared dissolving $2.2 \mathrm{mg}$ of the LOX in $0.5 \mathrm{~mL}$ of $0.1 \mathrm{~mol} \mathrm{~L}^{-1}$ phosphate buffer (potassium and sodium salts, $\mathrm{pH}$ 7.2) and stored at temperatures below than $0{ }^{\circ} \mathrm{C}$. Under these conditions the enzymatic activity remains stable for several weeks. A $0.028 \mathrm{~mol} \mathrm{~L}^{-1}$ stock solution of lactate (Merck) was prepared in deionized water. All other reagents were of analytical grade and the solutions were prepared just prior to use with deionized water processed through a water purification system (Nanopure Infinity, Barnstead). Samples of beers were purchased in a local supermarket. $\mathrm{CO}_{2}$ was removed from the samples by mechanical stirring for 5 minutes.

\section{Instrumentation}

A bipotentiostat from Autolab PGSTAT30 (Eco Chemie) connected to a personal computer was used in all electrochemical experiments. Voltammetric experiments were performed in a three-electrode cell by using a $\mathrm{Ag} / \mathrm{AgCl}, \mathrm{NaCl}$ sat. reference electrode, a platinum wire as auxiliary electrode and a glassy carbon electrode. The flow injection system consisted of a homemade injection valve with a loop volume of $50 \mu \mathrm{L}$, solutions being propelled by pressurization using a peristaltic pump (Ismatec, Switzerland) at $0.85 \mathrm{~mL}$ $\min ^{-1}$. The supporting electrolyte for FIA experiments consisted of PBS buffer, $\mathrm{pH}=6.9$. 
Modification of the electrode surface and enzyme immobilization

Prior to PB electrodeposition, the glassy carbon electrode surface was cleaned by using alumina powder, $1 \mu \mathrm{m}$ (Massachusetts, USA) and rinsing with deionized water. The PB film was deposited by potential cycling between -0.2 and $1.0 \mathrm{~V}$ at $50 \mathrm{mV} \mathrm{s}^{-1}$ in a solution containing $0.6 \mathrm{mmol} \mathrm{L}^{-1}$ $\mathrm{K}_{3} \mathrm{Fe}(\mathrm{CN})_{6}, 0.6 \mathrm{mmol} \mathrm{L}^{-1} \mathrm{Fe}(\mathrm{III}), 0.1 \mathrm{~mol} \mathrm{~L}^{-1} \mathrm{KCl}, 1 \mathrm{mmol} \mathrm{L}^{-1}$ $\mathrm{CTAB}$ at $\mathrm{pH}$ around 1.7 maintained with $\mathrm{HCl}$. After film formation, the stability of the electrochemical response was verified by cyclic voltammetry in a $0.1 \mathrm{~mol} \mathrm{~L}^{-1} \mathrm{KCl}$ solution (pH 1.7). LOX was immobilized onto the PB-modified glassy carbon electrode by placing measured amounts of enzyme solution on the electrode surface and allowing the droplets to dry at room temperature. The enzyme layer was covered by a Nafion layer by applying $10 \mu \mathrm{L}$ of $0.3 \%$ Nafion (prepared by diluting a 5\% Nafion solution with ethanol) and allowing the solvent to evaporate. The fabricated biosensor was then stored in a phosphate buffer solution ( $\mathrm{pH}$ 6.9).

\section{Amperometric determination of lactate in beer samples}

Lactate in beer samples was determined by using the proposed FIA amperometric method. Results were compared with those obtained by means of a commercial enzymatic spectrophotometric detection kit purchased from Boehringer Mannheim / R - Biopharm.

\section{Results and Discussion}

\section{Preparation of the PB modified electrode and electrocatalysis}

Glassy carbon electrodes were modified with a layer of hexacyanoferrate (HCF) according to the procedure described in the Experimental Section. The thickness of the film was found to grow with each potential cycle (voltammograms not shown). When the modified electrode is thoroughly rinsed with water and a new voltammogram is recorded in electrolyte solution, the response is retained and two pairs of anodic and cathodic peaks are observed, corresponding respectively to the following electrodic processes (curve b, Figure 1) also reported in literature:20-22

$$
\begin{array}{lc}
\mathrm{Fe}_{4}^{\mathrm{III}}\left[\mathrm{Fe}^{\mathrm{II}}(\mathrm{CN})_{6}\right]_{3}+4 \mathrm{~K}^{+}+4 \mathrm{e}^{-} \rightleftharpoons & \mathrm{K}_{4} \mathrm{Fe}_{4}{ }^{\mathrm{II}}\left[\mathrm{Fe}^{\mathrm{II}}(\mathrm{CN})_{6}\right]_{3} \\
\text { Prussian Blue "insoluble" } & \text { Prussian White } \\
\mathrm{Fe}_{4}^{\mathrm{III}}\left[\mathrm{Fe}^{\mathrm{II}}(\mathrm{CN})_{6}\right]_{3}+3 \mathrm{~A}^{-} \rightleftharpoons & \mathrm{Fe}_{4}^{\mathrm{III}}\left[\mathrm{Fe}^{\mathrm{III}}(\mathrm{CN})_{6} \mathrm{~A}\right]_{3}+3 \mathrm{e}^{-} \\
\text {Prussian Blue "insoluble" } & \text { Berlin Green }
\end{array}
$$

where $\mathrm{A}$ is the electrolyte anion.

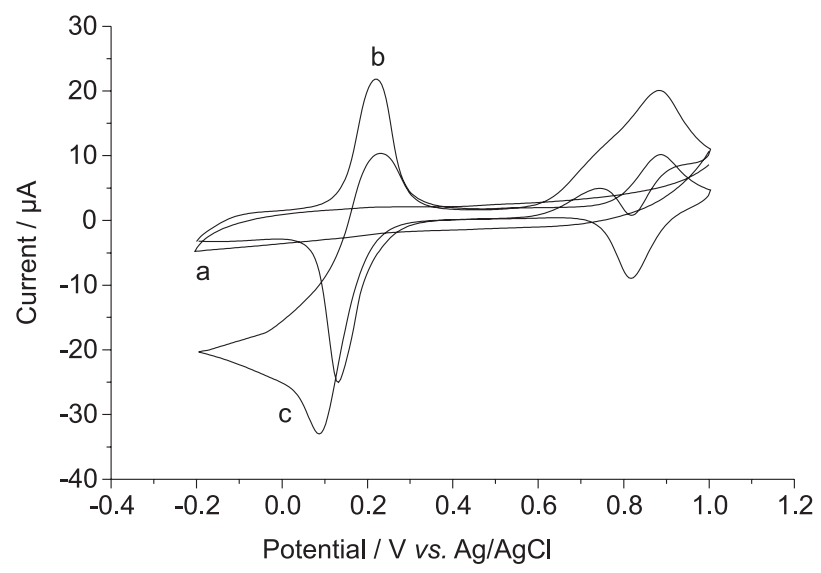

Figure 1. Cyclic voltammograms recorded with a FeHCF modified electrode before (b) and after (c) addition of hydrogen peroxide (final concentration $\left.=4.0 \mathrm{mmol} \mathrm{L}{ }^{-1}\right)$ to phosphate buffer $(\mathrm{pH} \mathrm{6.4})$. Curve (a) represents the cyclic voltammogram recorded with a bare glassy carbon electrode in the solution containing hydrogen peroxide. Scan Rate $=50 \mathrm{mV} \mathrm{s}^{-1}$.

At the experimental conditions shown in Figure 1, a film with $\Gamma=3.0 \times 10^{-9} \mathrm{~mol} \mathrm{~cm}^{-2}$ was obtained by measuring the charge under the first process at $0.22 \mathrm{~V}$. By adding hydrogen peroxide to the electrolyte solution and recording a new voltammogram (curve c, Figure 1) with the PB modified electrode, a remarkable current enhancement is noticed in the cathodic peak around $0.1 \mathrm{~V}$. This reductive electrodic process associated with the decrease in the corresponding anodic peak constitutes a clear evidence of the electrocatalytic reduction of hydrogen peroxide.

Figure 2 presents results on the comparison of the electrochemical behavior of $\mathrm{PB}$ modified electrodes prepared in the absence (PB) and presence (PB-CTAB) of CTAB in the working solution during film preparation as an attempt to corroborate the positive effects of the surfactant in the stability of the electrodeposited material. Upon continuous potential cycling of the PB-CTAB modified electrode in supporting electrolyte solution, no significant indication of signal loss is noticed, whereas a $64 \%$ current decrease is observed at the PB modified electrode after the same period of time (1920 s). Furthermore, a noticeable current difference is shown by comparing voltammetric curves in panels $\mathrm{A}$ and $\mathrm{B}$, this being another attractive characteristic of the PB electrodeposition process in medium containing CTAB. This enhanced electrochemical response has been attributable to the incorporation of high-spin $\mathrm{Fe}^{3+}$ ions into the PB lattice interstitial channels, allowing an increased quantity of the electroactive material and a more efficient charge transfer towards the electroreduction of $\mathrm{H}_{2} \mathrm{O}_{2} \cdot{ }^{18}$

A general problem with $\mathrm{PB}$ films is related with the exchange between sodium and potassium ions in the lattice. ${ }^{11,20}$ Experiments with PB films prepared in medium containing CTAB showed that the voltammetric behavior 

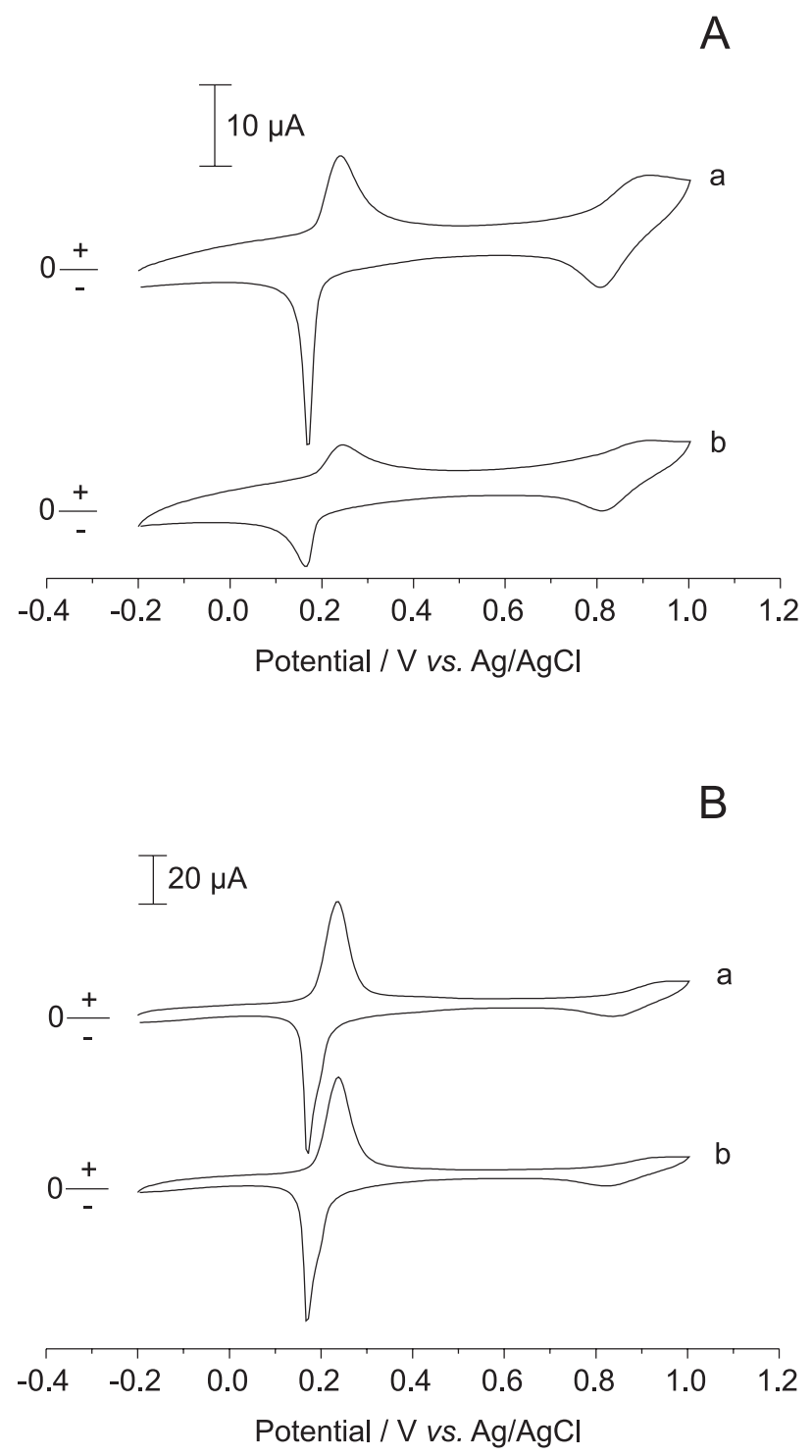

Figure 2. Evaluation of the stability of $\mathrm{PB}$ modified electrodes prepared in the absence (A) and presence (B) of CTAB. Cyclic voltammograms ((a) $1^{\circ}$ and (b) $60^{\circ}$ potential cycle) were recorded in a $0.1 \mathrm{~mol} \mathrm{~L}^{-1} \mathrm{KCl}$ solution (pH 1.7). Scan Rate $=50 \mathrm{mV} \mathrm{s}^{-1}$.

of the modified electrode is not changed significantly when the concentration ratio between potassium and sodium ions was varied in the range 1:1 to $1: 10$.

\section{Optimization of the biosensor response and analytical parameters}

PB modified electrodes containing lactate oxidase were used as amperometric detectors in the FIA system at $-0.1 \mathrm{~V}$ by taking into account an optimum compromise between both the sensitivity of measurements (curve c, Figure 1) and the influence of dissolved oxygen. The sensitivity of the sensor regarding the carrier solution $\mathrm{pH}$ was investigated by recording peak currents during additions of $0.28 \mathrm{mmol} \mathrm{L}^{-1}$ lactate solutions. Maximum sensitivity of the biosensor was achieved in the $\mathrm{pH}$ range around 6.9, a significant current decrease being observed at more acidic or alkaline conditions (Figure 3). On the other hand, the response of the PB modified electrode to hydrogen peroxide is increased as the $\mathrm{pH}$ is lowered, in agreement with reports from literature. ${ }^{3}$ The results obtained with the biosensor are expected as the enzyme is more active in solutions close to neutrality. However, the $\mathrm{pH}$ value of 6.9 was chosen as optimum for biosensor operation in all subsequent experiments because the decrease in sensitivity at this $\mathrm{pH}$ value is not significant taking into consideration the relatively high concentration of lactate in the beer samples.

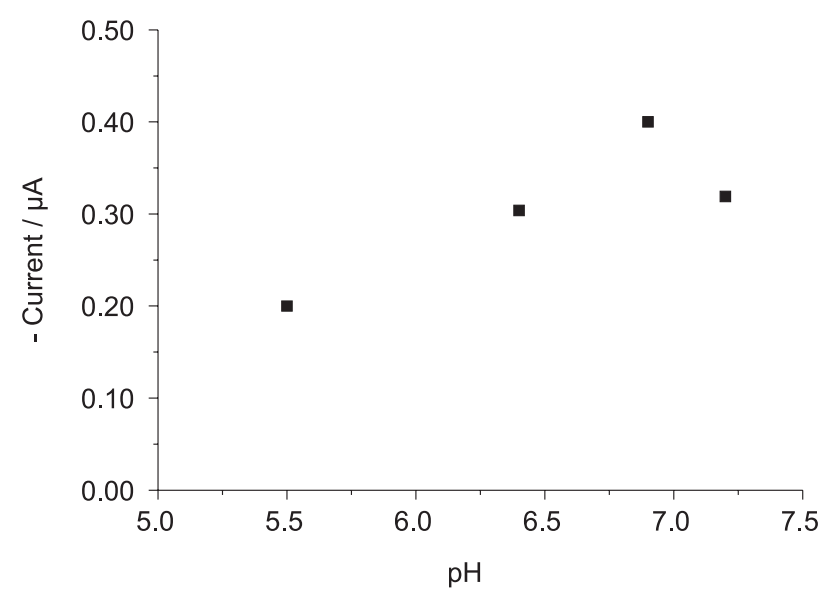

Figure 3. Dependence of the FIA response on the $\mathrm{pH}$ for injections of $0.28 \mathrm{mmol} \mathrm{L}^{-1}$ lactate. Amount of immobilized LOX $=1 \mathrm{U}$.

The influence of parameters such as flow rate and sample volume injected was also investigated in FIA experiments. The signal increases when the flow rate was varied in the range 0.1 to $1.2 \mathrm{~mL} \mathrm{~min}^{-1}$, which is an indication that the electrode process is mass-transport controlled. The flow rate of $0.85 \mathrm{~mL} \mathrm{~min}^{-1}$ was selected as the most favourable taking into account the sensitivity of the measurements and consumption of the carrier solution. The influence of the sample volume on the analytical signal was also studied and loops of 25, 50,100 and $150 \mu \mathrm{L}$ were tested. The $50 \mu \mathrm{L}$ sample volume was selected as the working volume in the following experiments.

In order to investigate the repeatability of the biosensor response, repetitive injections of a lactate standard were done within a period of $6 \mathrm{~min}$. Figure 4 shows typical FIA responses relating this experiment and the relative standard deviation was found to be $2.2 \%(n=18)$. A linear calibration plot was obtained in the range 0.004 to $0.280 \mathrm{mmol} \mathrm{L}^{-1}$ lactate $\left(\mathrm{I}(\mu \mathrm{A})=6 \times 10^{-3}+1.36 \mathrm{C}_{\text {lactate }}\left(\mathrm{mmol}^{-1}\right), \mathrm{r}^{2}=0.99978\right)$ and the limit of detection, measured as the ration between the slope of the calibration plot and the standard deviation 
of the background, was found to be $0.84 \mu \mathrm{mol} \mathrm{L}^{-1}$ for a freshly prepared biosensor. This value is comparable to the one reported in literature based on immobilization of lactate dehydrogenase and toluidine blue $\mathrm{O}$ by using a dialysis membrane and better than other two lactate biosensors where lactate oxidase was used as enzyme. ${ }^{24,25}$ The analytical frequency was estimated to be 200 samples $\mathrm{h}^{-1}$. The variability of measurements (inter-assay reproducibility) performed with three different biosensors was found to be $9 \%$, demonstrating that differences in operator behavior to fabricate the biosensor are no relevant. The long-term storage of the biosensor was studied over a 14-day period during which it was stored in a fridge at $5^{\circ} \mathrm{C}$. A significant decrease in the sensitivity was observed in the first day (23\%) and then a slight decrease was noticed in the subsequent days. ${ }^{23}$ Such lack of long-term behavior may be an indication of both a lixiviation of the enzyme or activity decrease. The loss of enzyme is not likely to occur as the surface of the biosensor is covered with Nafion. Hence, a much more plausible explanation involves the enzyme consumption by relatively high concentrations of L-lactate employed in this study $\left(0.28 \mathrm{mmol} \mathrm{L}^{-1}\right)$. The decrease on the amount of Prussian blue film on the surface of the electrode could be also responsible for the decrease in the sensitivity, as already stated in literature. ${ }^{26}$ However, the good repeatability of the biosensor at relatively short time experiments (Figure 4) and the reasonable sensitivity suggest its usefulness to monitor lactate in beer samples.

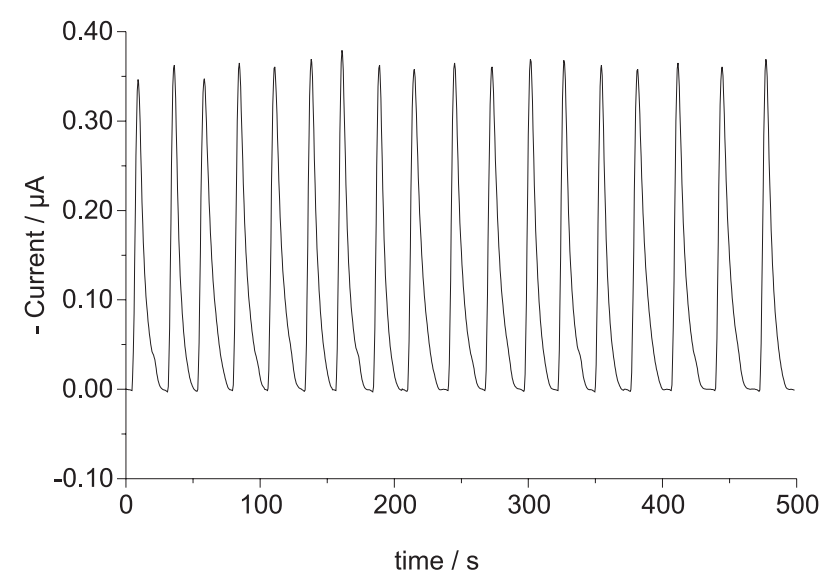

Figure 4. FIA responses on repetitive injections of $0.28 \mathrm{mmol} \mathrm{L}^{-1}$ lactate. $\mathrm{E}=-0.1 \mathrm{~V}$. Flow rate $=0.85 \mathrm{~mL} \mathrm{~min}^{-1} . \mathrm{pH}=6.9$. Amount of immobilized $\mathrm{LOX}=1 \mathrm{U}$.

Investigations on the existence of interference from interfering species in beer samples were also performed to ensure selectivity of the lactate biosensor. This was accomplished for two main potentially compounds commonly coexisting in the analysed samples, i.e., ascorbic acid and glucose. The performance of the biosensor was evaluated at high concentrations of both substances $\left(1 \mathrm{mmol} \mathrm{L}^{-1}\right)$ and the obtained results were normalized with respect to the current response for lactate. Negligible changes in current following addition of ascorbic acid and glucose were noticed, confirming the high selectivity of the proposed device owing to the relatively low applied potential $(-0.1 \mathrm{~V})$.

\section{Lactate FIA determination in beer samples}

After optimization of experimental parameters, the biosensor was used to monitor lactate in beer samples as reported in the Experimental section. The results were obtained by comparing signals in the FIA recordings with those from injection of lactate standard solutions. Figure 5 shows a typical FIA recording where triplicate responses to both standards and samples are observed. Table 1 reports the results obtained with the proposed amperometric method and by using a spectrophotometric enzymatic commercial kit. The good agreement between results shown in this table confirms that the amperometric sensor associated to the FIA apparatus consists of a reliable methodology to determine lactate in beer samples.

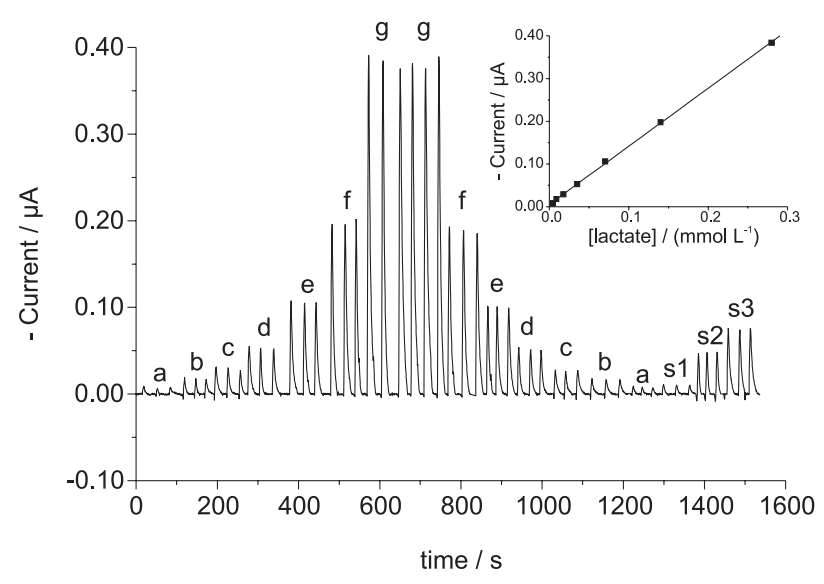

Figure 5. Peaks recorded for standard lactate solutions: (a) $4.4 \mu \mathrm{mol} \mathrm{L}^{-1}$, (b) $8.8 \mu \mathrm{mol} \mathrm{L}^{-1}$, (c) $17.5 \mu \mathrm{mol} \mathrm{L}-1$, (d) $35 \mu \mathrm{mol} \mathrm{L}^{-1}$, (e) $70 \mu \mathrm{mol} \mathrm{L}{ }^{-1}$, (f) $140 \mu \mathrm{mol} \mathrm{L} \mathrm{L}^{-1}$, (g) $280 \mu \mathrm{mol} \mathrm{L}-1$ and beer samples (s1, s2 and s3). $\mathrm{E}=-0.1 \mathrm{~V}$; flow rate $=0.85 \mathrm{~mL} \mathrm{~min}^{-1} ; \mathrm{pH}=6.9$; amount of immobilized $\mathrm{LOX}=1 \mathrm{U}$.

Table 1. Lactate content in different samples

\begin{tabular}{lcc}
\hline Samples & \multicolumn{2}{c}{ Methods } \\
\cline { 2 - 3 } & FIA / $\left(\mathrm{mmol} \mathrm{L}^{-1}\right)$ & Enzymatic kit / $\left(\mathrm{mmol} \mathrm{L}^{-1}\right)$ \\
\hline 1 & $1.4 \pm 0.1$ & $1.65 \pm 0.07$ \\
2 & $2.68 \pm 0.09$ & $2.60 \pm 0.06$ \\
3 & $2.82 \pm 0.05$ & $2.8 \pm 0.1$ \\
4 & $1.66 \pm 0.01$ & $1.56 \pm 0.06$ \\
\hline
\end{tabular}




\section{Conclusions}

In this paper we presented results on the fabrication of a lactate biosensor using a PB film as signal transducer. The stability of the PB film was enhanced by adding CTAB to the electrodeposition solution, a better sensitivity being also noticed. The device is proved to have high accuracy, relatively low limit of detection and a fast throughput. The use of the proposed amperometric detector in FIA systems was conveniently demonstrated by measuring the concentration of lactate in beer samples and the reliability of the method was satisfactory by comparing the results with those obtained using a commercial kit. This was possible owing to the operation of the biosensor at a potential region where interferences are not electroactive. Hence, some fundamental information has been provided for further optimization to meet any specific requirement in lactate detection.

\section{Acknowledgments}

This work was supported by FAPESP (Fundação de Amparo à Pesquisa de São Paulo) and CNPq (Conselho Nacional de Desenvolvimento Científico e Tecnológico).

\section{References}

1. Itaya, K.; Shoji, N.; Uchida, I.; J. Am. Chem. Soc. 1984, 106, 3423.

2. Itaya, K.; Uchida, I.; Neff, V. D.; Acc. Chem. Res. 1986, 19, 162.

3. Garjonyte, R.; Malinauskas, A.; Sens. Actuators B, Chem. 1998, 46, 236.

4. Karyakin, A. A.; Karyakina, E. E.; Gorton, L.; Electrochem. Commun. 1999, 1, 78.

5. Lin, M. S.; Jan, B. I.; Electroanalysis 1997, 9, 340.

6. Tsiafoulis, C. G.; Trikalitis, P. N.; Prodromidis, M. I.; Electrochem. Commun. 2005, 7, 1398.
7. Joseph, J.; Gomathi, H.; Rao, G. P.; Electrochim Acta 1991, 36, 1537.

8. Joseph, J.; Gomathi, H.; Rao, G. P.; J. Electroanal. Chem. 1997, $431,231$.

9. Tacconi, N. R.; Rajeshwar, K.; Lezna, R. O.; Chem. Mater. 2003, 15, 3046.

10. Chen, S. -M.; Electrochim. Acta 1998, 43, 3359.

11. Chen, S. -M.; J. Electroanal. Chem. 2002, 521, 29.

12. Eftekhari, A; J. Electroanal. Chem. 2002, 537, 59.

13. Garjonyte, R.; Malinauskas, A.; Sens. Actuators B, Chem. 1999, $56,93$.

14. Cataldi, T. R. I.; Benedetto, G.; Bianchini, A.; J. Electroanal. Chem. 1999, 471, 42.

15. Oliveira, M. S.; Paixão, T. R. L. C.; Bertotti, M.; Int. J. Electrochem. Sci. 2007, 2, 248.

16. Zen, J. -M.; Chen, P. -Y.; Kumar, A. S.; J. Chin. Chem. Soc. (Taipei, Taiwan) 2002, 49, 915.

17. Vittal, R.; Gomathi, H.; J. Phys. Chem. B 2002, 106, 10135.

18. Kumar, S. M. S.; Pillai, K. C.; Electrochem. Commun. 2006, 8 , 621.

19. Mattos, I. L.; Gorton, L.; Laurell, T.; Malinauskas, A.; Karyakin, A. A.; Talanta 2000, 52, 791.

20. Karyakin, A. A.; Electroanalysis 2001, 13, 813.

21. Koncki, R.; Crit. Rev. Anal. Chem. 2002, 32, 79.

22. Ricci, F.; Palleschi, G.; Biosens. Bioelectron. 2005, 21, 389.

23. Lowinsohn, D.; Bertotti, M.; Anal. Biochem. 2007, 365, 260.

24. Villamil, M. J. F.; Ordieres, A. J. M.; Blanco, P. T.; Anal. Chim. Acta 1997, 345, 37.

25. Parra, A.; Casero, E.; Vasquez, L.; Pariente, F.; Lorenzo, E.; Anal. Chim. Acta 2006, 555, 308.

26. Garjonyte, R.; Yigzaw, Y.; Meskys, R.; Malinauskas, A.; Gorton, L.; Sens. Actuators B, Chem 2001, 79, 33.

Received: August 1, 2007

Web Release Date: February 29, 2008

FAPESP helped in meeting the publication costs of this article. 